Article

\title{
A New Polyunsaturated Brominated Fatty Acid from a Haliclona Sponge
}

\author{
Satoe Aratake ${ }^{1}$, Agus Trianto ${ }^{1,2}$, Novriyandi Hanif ${ }^{3}$, Nicole J. de Voogd ${ }^{4}$ and \\ Junichi Tanaka $^{1, *}$
}

1 Department of Chemistry, Biology and Marine Science, University of the Ryukyus, Nishihara, Okinawa 903-0213, Japan; E-Mail: k088302@eve.u-ryukyu.ac.jp (S.A.)

2 Department of Marine Science, Diponegoro University, Semarang 50234, Indonesia; E-Mail: trianto_telawur@yahoo.co.id (A.T.)

3 Department of Chemistry, Graduate School of Science, Nagoya University, Furo-cho, Chikusa-ku, Nagoya 464-8602, Japan; E-Mail: novriyandi@hotmail.com (N.H.)

4 Naturalis, National Museum of Natural History, PO Box 9517, 2300 RA Leiden, The Netherlands; E-Mail: voogd@naturalis.nnm.nl (N.J.d.V.)

* Author to whom correspondence should be addressed; E-Mail: jtanaka@sci.u-ryukyu.ac.jp; Tel.: +81-98-895-8560; Fax: +81-98-895-8565.

Received: 22 September 2009; in revised form: 27 October 2009 / Accepted: 30 October 2009 / Published: 2 November 2009

\begin{abstract}
A new polyunsaturated brominated fatty acid possessing acetylenic bonds $\mathbf{1}$ was isolated from the Indonesian sponge Haliclona sp. The structure of compound $\mathbf{1}$ was elucidated by analyzing its spectral data. It showed moderate cytotoxicity against cultured cells.
\end{abstract}

Keywords: sponge; fatty acid; cytotoxicity

\section{Introduction}

To date a number of linear acetylenic compounds have been isolated from marine organisms. Among them, sponges are the most prolific sources of molecules of this class. Representative members retain unique structures and show biomedical potential, e.g., lembehynes showing neuritogenic activity [1], petrosynol and petrosynolic acid inhibiting reverse transcriptase of human immunodeficiency virus [2], pellynols showing potent cytotoxicity [3], and a thiophene-containing 
fatty acid showing antimicrobial activity [4]. In our quest to discover new bioactive molecules from marine invertebrates of the Okinawan and Indonesian coral reefs, we screened extracts prepared from specimens collected around Alor Island, Indonesia. A lipophilic extract of the sponge Haliclona sp. showed cytotoxicity against cultured cells, and hence, we isolated its active constituent, the structure of which is the subject of this manuscript.

\section{Results and Discussion}

The sponge was extracted with acetone. Its lipophilic extract was separated on a silica gel column, followed by reverse-phase HPLC to yield compound $\mathbf{1}$ as an oil, which gradually decomposes during handling. The molecular formula of the compound was $\mathrm{C}_{20} \mathrm{H}_{21} \mathrm{BrO}_{2}$ by ESITOFMS, indicating ten degrees of unsaturation. This could be accounted for by the presence of five olefins (ten signals from $\delta 110.1$ to 140.9 ), two acetylenes ( $\delta 68.9 \mathrm{~d}, 80.0 \mathrm{~s}, 83.6 \mathrm{~s}, 89.6 \mathrm{~s}$ ), and one carboxylic acid ( $\delta 174.0$; $1,713 \mathrm{~cm}^{-1}$ ). Strong UV absorption at $256 \mathrm{~nm}$ suggested the presence of conjugated systems.

Four partial structures i-iv were revealed by inspecting COSY cross peaks (Table 1): (i) a diene (a vinyl proton at $\delta 6.67(\mathrm{H}-5)$ next to cis olefinic protons at $\delta 5.67$ and 6.23) with a methylene at $\delta 3.20$ (H-2), (ii) a double bond ( $\delta 5.47$ and 5.63; H-8,9) flanked by two methylenes at $\delta 3.39(\mathrm{H}-7)$ and 3.15 (H-10), (iii) conjugated trans double bonds ( $\delta$ 5.52, 6.50, 6.13, and 5.79; H-13 to H-16) with a methylene at $\delta 2.31$ (H-17), and (iv) a terminal acetylenic proton at $\delta 1.90(\mathrm{H}-20)$ with a methylene at $\delta 2.28$ (H-18). The remaining substituted acetylene should be placed between units ii and iii because HMBC correlations H-10/C-11,12 and H-14/C-12 were observed. Additional HMBC correlations enabled us to connect the following units: $\mathbf{i}$ and ii (H-5/C-6,7 and H-7/C-5,6), iii and iv (H-17/C-18 and $\mathrm{H}-18 / \mathrm{C}-17)$, and $\mathbf{i}$ and the carboxylic acid (H-2/C-1). Bromine was placed at the sole quaternary olefinic carbon at C-6. NOE between $\mathrm{H}-7$ and $\mathrm{H}-4$ determined $5 E$ configuration, while $8 \mathrm{Z}$ configuration was assigned by the $J$ value $(10.5 \mathrm{~Hz})$ between $\mathrm{H}-8$ and $\mathrm{H}-9$ with decoupling experiments. Therefore, the entire structure was elucidated to be 6-bromo-icosa-3Z,5E,8Z,13E,15Epentaene-11,19-diynoic acid. Although more than twenty fatty acids with bromination at C-6 have been reported [5-11], compound $\mathbf{1}$ had the highest unsaturation degree of this class.

Figure 1. Structure of Compound 1.

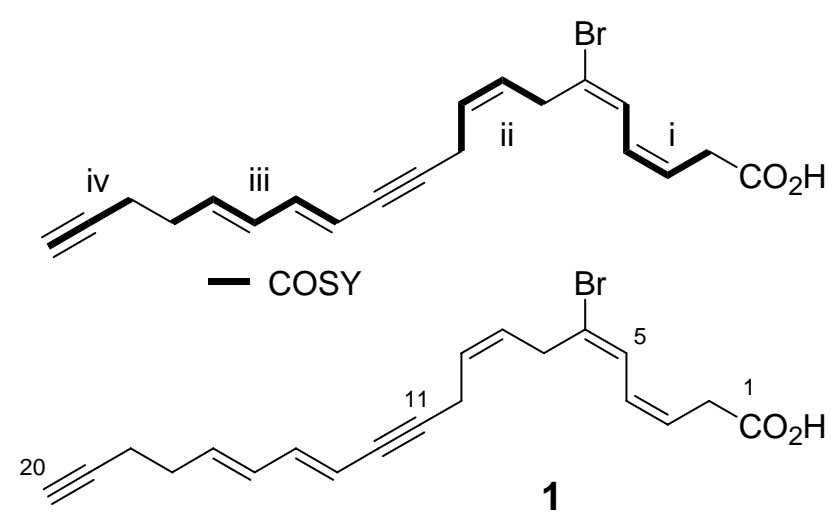


Table 1. ${ }^{1} \mathrm{H}$ - and ${ }^{13} \mathrm{C}-\mathrm{NMR}$ Data (in $\mathrm{CDCl}_{3}$ ) for compound $\mathbf{1}$.

\begin{tabular}{lrlll}
\hline C\# & \multicolumn{1}{c}{$\boldsymbol{\delta C}$} & \multicolumn{1}{c}{$\delta \mathbf{H}(\mathbf{m u l t} ., \boldsymbol{J}$ in Hz) } & \multicolumn{1}{c}{ COSY } & \multicolumn{1}{c}{ HMBC } \\
\hline 1 & $174.0 \mathrm{~s}$ & & & \\
2 & $32.8 \mathrm{t}$ & $3.20(\mathrm{~d}, J=6.8)$ & $\mathrm{H}-3$ & $\mathrm{C}-1,3,4,7$ \\
3 & $125.3 \mathrm{~d}$ & $5.67(\mathrm{dt}, \mathrm{J}=11.2,6.8)$ & $\mathrm{H}-2,4$ & $\mathrm{C}-5$ \\
4 & $125.4 \mathrm{~d}$ & $6.23(\mathrm{dd}, J=11.5,11.2)$ & $\mathrm{H}-3,5$ & $\mathrm{C}-2$ \\
5 & $127.1 \mathrm{~d}$ & $6.67(\mathrm{~d}, J=11.5)$ & $\mathrm{H}-4$ & $\mathrm{C}-3,6,7$ \\
6 & $128.6 \mathrm{~s}$ & & & \\
7 & $34.2 \mathrm{t}$ & $3.39(\mathrm{brd}, J=7.1)$ & $\mathrm{H}-8$ & $\mathrm{C}-2,5,6,8$ \\
8 & $126.6 \mathrm{~d}$ & $5.47(\mathrm{dtt}, J=10.5,1.7,7.1)$ & $\mathrm{H}-7,9$ & $\mathrm{C}-10$ \\
9 & $126.9 \mathrm{~d}$ & $5.63(\mathrm{dtt}, J=10.5,7.1,1.7)$ & $\mathrm{H}-8,10$ & $\mathrm{C}-7$ \\
10 & $18.4 \mathrm{t}$ & $3.15(\mathrm{brd}, J=7.1)$ & $\mathrm{H}-9,13$ & $\mathrm{C}-8,11,12$ \\
11 & $89.6 \mathrm{~s}$ & & & \\
12 & $80.0 \mathrm{~s}$ & & & $\mathrm{C}-15$ \\
13 & $110.1 \mathrm{~d}$ & $5.52(\mathrm{brd}, J=15.6)$ & $\mathrm{H}-10,14$ & $\mathrm{C}-12$ \\
14 & $140.9 \mathrm{~d}$ & $6.50(\mathrm{dd}, J=15.6,10.7)$ & $\mathrm{H}-13,15$ & $\mathrm{C}-13,17$ \\
15 & $130.9 \mathrm{~d}$ & $6.13(\mathrm{dd}, J=15.4,10.7)$ & $\mathrm{H}-14,16$ & $\mathrm{C}-14,17$ \\
16 & $134.3 \mathrm{~d}$ & $5.79(\mathrm{dt}, J=15.4,6.1)$ & $\mathrm{H}-15,17$ & $\mathrm{C}-15,16,18$, \\
17 & $31.6 \mathrm{t}$ & $2.31(\mathrm{~m})$ & $\mathrm{H}-16$ & 20 \\
18 & $18.3 \mathrm{t}$ & $2.28(\mathrm{~m})$ & $\mathrm{H}-20$ & $\mathrm{C}-17,19,20$ \\
19 & $83.6 \mathrm{~s}$ & & & \\
\hline 20 & $68.9 \mathrm{~d}$ & $1.90(\mathrm{t}, J=2.4)$ & $\mathrm{H}-18$ & \\
\hline
\end{tabular}

We evaluated the cytotoxicity of the purified molecule 1 against NBT-T2 rat bladder epithelial cells, and the IC50 value was estimated to be $36 \mu \mathrm{g} / \mathrm{mL}$. This weaker activity than the original extract was because of the presence of other toxic components and/or decomposition of the molecule during the assay.

\section{Experimental Section}

\subsection{General Procedures}

ESIMS was measured on a PE QSTAR mass spectrometer. FTIR and UV spectra were obtained on Varian FTS-3000 and Hitachi U-2000 instruments. ${ }^{1} \mathrm{H}$ - and ${ }^{13} \mathrm{C}$ - as well as 2D NMR spectra were obtained on a Jeol A500 spectrometer in $\mathrm{CDCl}_{3}$ with reference to an internal standard of TMS. Chemical shifts and coupling constants were expressed in $\delta$ and $\mathrm{Hz}$.

\subsection{Animal Material}

The sponge shown below in Figure 2 was collected at a depth range of 20-35 m by hand during scuba diving on the strait between Alor and Pantar Islands, Nusa Tengara Timur, Indonesia. The specimen was identified by one of the authors (NJdV) as Haliclona sp., Chalinidae, Haplosclerida, and deposited at Naturalis, National Museum of Natural History, Leiden, the Netherlands, with a code RMNH POR 4825. 
Figure 2.

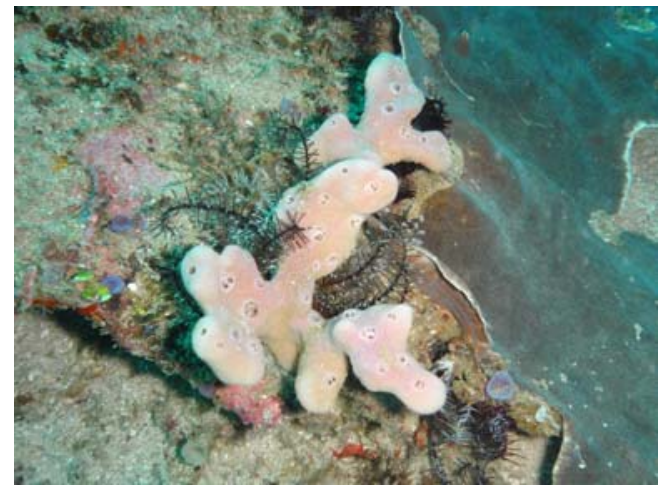

\subsection{Isolation of compound $\mathbf{1}$}

The frozen sponge (wet weight, $43.4 \mathrm{~g}$ ) was cut and steeped in acetone (200 $\mathrm{mL}$ ) three times. The combined acetone solution was concentrated under vacuum, and the resulting residue was partitioned between EtOAc and water. The organic layer yielded $365 \mathrm{mg}$ of a crude oil showing cytotoxicity at $1 \mu \mathrm{g} / \mathrm{mL}$. The extract was separated on a silica gel with stepwise elution (Hexane-EtOAc: 1-0, 10-1, 1-1, 0-1, and $\mathrm{MeOH}$ ) to give six fractions. Of these, the fifth fraction (18.5 mg) eluted with EtOAc was further separated by reverse-phase HPLC (RP-18, $\mathrm{MeOH}-\mathrm{H}_{2} \mathrm{O}, 50-1$ ) to yield compound 1 (7.9 mg). An additional amount was obtained from recollected specimens.

\subsection{Compound 1}

Oil. HRESIMS $\mathrm{m} / \mathrm{z}$ 395.0604, 397.0601 (calcd. for $\mathrm{C}_{20} \mathrm{H}_{21} \mathrm{BrO}_{2} \mathrm{Na}$, 395.0623, 397.0602); FTIR (neat) 3,295, 3,026, 2,925, 2,361, 2,214, 2,116, 1,713, 1,593 cm ; UV $\lambda \max 256 \mathrm{~nm}(\log \varepsilon$ 4.5, $\mathrm{MeOH})$; and ${ }^{1} \mathrm{H}$ - and ${ }^{13} \mathrm{C}-\mathrm{NMR}$ see Table 1.

\subsection{Cytotoxicity testing}

NBT-T2 rat bladder epithelial cells (BRC-1370, purchased from Riken BioResource Center) were cultured in DMEM supplemented with $10 \%$ heat-inactivated fetal bovine serum and antimicrobial agents using a standard protocol and seeded in $200 \mu \mathrm{L}$ wells. After preincubation $\left(37^{\circ} \mathrm{C}, 24 \mathrm{~h}\right.$ ), cells were exposed to graded concentrations of compounds in duplicate $\left(37^{\circ} \mathrm{C}, 48 \mathrm{~h}\right)$. The cells were treated with MTT solution (15 $\mu \mathrm{L}, 5 \mathrm{mg} / \mathrm{mL}$ in PBS) after removal of the medium and incubated for $3 \mathrm{~h}$. Residual formozan was dissolved in DMSO (100 $\mu \mathrm{L})$ and absorbance was measured using a Tecan Sunrise microplate reader at $560 \mathrm{~nm}$. IC50 values were estimated by plotting absorbance values against concentrations.

\section{Acknowledgements}

We thank PharmaMar S.A. for their support. 


\section{References}

1. Aoki, S.; Matsui, K.; Wei, H.; Murakami, N.; Kobayashi, M. Structure-activity relationship of neuritogenic spongean acetylene alcohols, lembehynes. Tetrahedron 2002, 58, 5417-5422.

2. Rashid, M.A.; Gustafson, K.R.; Boyd, N.R. Pellynol I. A new cytotoxic polyacetylene from the sponge Pellina sp. Nat. Prod. Lett. 2000, 14, 387-392.

3. Isaacs, S.; Kashman, Y.; Loya, S.; Hizi, A.; Loya, Y. Petrosynol and petrosolic acid, two novel natural inhibitors of the reverse transcriptase of human immunodeficiency virus from Petrosia sp. Tetrahedron 1993, 49, 10435-10438.

4. Tianero, M.D.B.; Hanif, N.; de Voogd, N.J.; van Soest, R.W.M.; Tanaka, J. A new antimicrobial fatty acid from the Calcareous sponge Paragrantia cf. waguensis. Chem. Biodivers. 2009, 6, 1374-1377.

5. Brantley, S.E.; Molinski, T.F.; Preston, C.M.; DeLong, E.F. Brominated acetylenic fatty acids from Xestospongia sp., a marine sponge-bacteria association. Tetrahedron 1995, 51, 7667-7672.

6. Carballeira, N.M.; Shalabi, F. Novel brominated phospholipid fatty acids from the Caribbean sponge Petrosia sp. J. Nat. Prod. 1993, 56, 739-746.

7. Garson, M.J.; Zimmermann, M.P.; Hoberg, M.; Larsen, R.M.; Battershill, C.N.; Murphy, P.T. Isolation of brominated long-chain fatty acids from the phospholipids of the tropical marine sponge Amphimedon terpenensis. Lipids 1993, 28, 1011-1014.

8. Ichiba, T.; Scheuer, P.J.; Kelly-Borges, M. Sponge-derived polyunsaturated $\mathrm{C}_{16}$ di- and tribromocarboxylic acids. Helv. Chim. Acta 1993, 76, 2814-2816.

9. Garson, M.J.; Zimmermann, M.P.; Battershill, C.N.; Holden, J.L.; Murphy, P.T. The distribution of brominated long-chain fatty acids in sponge and symbiont cell types from the tropical marine sponge Amphimedon terpenensis. Lipids 1994, 29, 509-516.

10. Li, Y.; Ishibashi, M.; Sasaki, T.; Kobayashi, J. New bromine-containing unsaturated fatty acid derivatives from the Okinawan marine sponge Xestospongia sp. J. Chem. Res. (S) 1995, 126-127.

11. Mansoor, T.A.; Bae, B.H.; Hong, J.; Lee, C.-O.; Im, K.S.; Jung, J.H. New fatty acid derivatives from Homaxinella sp., a marine sponge. Lipids 2005, 40, 981-985.

Samples Availability: Distribution is not planned, because of the unstable nature of the molecule.

(C) 2009 by the authors; licensee Molecular Diversity Preservation International, Basel, Switzerland. This article is an open-access article distributed under the terms and conditions of the Creative Commons Attribution license (http://creativecommons.org/licenses/by/3.0/). 